\title{
Real-time PCR in Food Science: PCR Diagnostics
}

\author{
David Rodríguez-Lázaro*1, Nigel Cook ${ }^{2}$ and Marta \\ Hernández ${ }^{3}$
}

${ }^{1}$ Microbiology Section, University of Burgos, Burgos, Spain

${ }^{2}$ Food and Environment Research Agency (FERA), York, UK

${ }^{3}$ Instituto Tecnológico Agrario de Castilla y León (ITACyL), Valladolid, Spain

\begin{abstract}
A principal consumer demand is a guarantee of the safety and quality of food. The presence of foodborne pathogens and their potential hazard, the use of genetically modified organisms (GMOs) in food production, and the correct labelling in foods suitable for vegetarians are among the subjects where society demands total transparency. The application of controls within the quality assessment programmes of the food industry is a way to satisfy these demands, and is necessary to ensure efficient analytical methodologies are possessed and correctly applied by the Food Sector. The use of real-time PCR has become a promising alternative approach in food diagnostics. It possesses a number of advantages over conventional culturing approaches, including rapidity, excellent analytical sensitivity and selectivity, and potential for quantification. However, the use of expensive equipment and reagents, the need for qualified personnel, and the lack of standardized protocols are impairing its practical implementation for food monitoring and control.
\end{abstract}

\section{Introduction}

The promotion of a high level of food safety is a major policy priority worldwide (Rodríguez-Lázaro, 2013). Foodborne diseases are among the most serious public health concerns worldwide, because they are a major cause of morbidity. More than 200 known diseases are transmitted through food, with symptoms ranging from mild gastroenteritis to life-threatening syndromes such as fulminant hepatitis, with the possibility of chronic complications or disability (Mead et al., 1999). Their incidence has been increased considerably during the last decades by the rapid globalization of the food market, the increase of population and food transportation, and profound changes in food consumption habits (Rodríguez-Lázaro et al., 2007; Rodríguez-Lázaro, 2013). The impact of foodborne pathogens in public health systems is considerable. Foodborne pathogens cause 47.8 million episodes, 127,839 hospitalizations and 3037 deaths per year in USA (Scallan et al., 2011a,b), with annual medical and productivity losses around 6500 million dollars due only to the five major foodborne pathogens (Crutchfield and Roberts, 2000). A similar impact has been recorded in the UK (Adak et al., 2005). In consequence, microbiological quality control programmes are increasingly applied throughout the food production chain in order to minimize the risk of infection for the consumer. The

*Corresponding author: Email: drlazaro@ubu.es development and optimization of novel alternatives for the monitoring, characterization and enumeration of foodborne pathogens is one of the key aspects of food microbiology (Stewart, 1997), and has become increasingly important in the agricultural and food industry (Malorny et al., 2003). Classical microbiological methods for the presence of microorganisms in foods involve, in general, pre-enrichment and isolation of presumptive colonies of bacteria on solid media, and final confirmation by biochemical and/or serological identification. Thus, they are laborious, timeconsuming and not always reliable (e.g. viable but nonculturable cells which are not detected) (Rollins and Colwell, 1986; Tholozan et al., 1999).

Other aspects in food safety and quality which are of concern for consumers include the use of genetically modified products as food ingredients. Genetically modified plants for human consumption or animal feed are mainly grown in the USA and Canada, with increasing production in Brazil, Argentina and China. Whilst GM food is readily accepted in the USA, European consumers have shown considerable reluctance due to a lack of confidence in food safety following previous food crises (Eurobarometer, 2005). Detection and traceability of GMOs resembles many issues in related fields of food microbiology diagnostics, and similar approaches may be applied. The definition of percentage GMO in a sample is a major unresolved problem. The determination of the percentage of adventitious GMO presence in a sample can be simple and reproducible, but not if the GMO is unknown or unauthorized, or present in mixtures or stacked versions. Therefore, there is a general need for improvement of qPCR techniques for rapid screening and analysis of unknown GMOs. Harmonization of decision trees common to all stakeholders and regulatory agencies is required.

Nucleic acid amplification by polymerase chain reaction $(\mathrm{PCR})$ is being promoted as the most promising alternative to conventional methods in food diagnostics (RodríguezLázaro et al., 2007). Visualization of a signal from a PCR assay was conventionally performed by visualization of amplicons after gel electrophoresis, but this approach has been mostly superseded by so real-time PCR (qPCR), in which sequence-specific fluorescent probes bind to the amplicon and are visualized as the amplicons accumulate (Heid et al., 1996). Major advantages of qPCR for its application in diagnostic food laboratories include rapidity and simplicity to perform analysis, the closed-tube format that avoids risks of carry-over contamination, the extremely wide dynamic range of quantification (more than eight orders of magnitude) (Heid et al., 1996), and the significantly higher reliability of the results compared to conventional methods. Progressive developments have resulted in qPCR-based methods being developed for accurate quantification of several analytes (organisms, GM sequences) in food analysis (Rodríguez-Lázaro et al., 2007).

\section{Current challenges}

The inherent advantages of amplification techniques (e.g. shorter turnaround, improved detection limits, 
Table 1. Sample preparation procedures used for different types of samples adapted from Rådström et al. (2003)

\begin{tabular}{llll}
\hline Category & Subcategory & Sample preparation procedure & Sample \\
\hline Biochemical & Adsorption & Lectin-based separation & Beef meat \\
& & Protein adsorption & Blood \\
& Nucleic acids extraction & Nucleic acid purification procedures & Diverse matrixes \\
& & Lytic procedures & Diverse matrixes \\
Immunological & Adsorption & Immunomagnetic capture & Diverse matrixes \\
Physical & & Aqueous two-phase systems & Soft cheese \\
& & Buoyant density centrifugation & Minced meat \\
& Centrifugation & Diverse matrixes \\
& & Dilution & Diverse matrixes \\
& Filtration & Diverse matrixes \\
& Mechanical disruption by ceramic spheres & Diverse matrixes \\
& Grinding by mortar and pestle & Diverse matrixes \\
Physiological & Boiling & Diverse matrixes \\
\hline
\end{tabular}

specificity and potential for automation) should foster their implementation in food laboratories. PCR was predicted to be established as a routine reference by 2010 (Hoorfar and Cook, 2003); however, this did not happen, and further developments are needed for effective implementation of PCR in food diagnostics (D'Agostino and RodríguezLázaro, 2009). The main issues that must be addressed for the effective adaptation of molecular techniques in food laboratories are: the development of rational and easyto-use strategies for pre-PCR treatment of food samples; the design and application of analytical controls; the development of strategies for the quantitative use of qPCR for food samples, greater automation of the whole analytical process, and in the particular case of food microbiology the inability to unambiguously detect viable organisms. Largescale international validation of the PCR-based methods against the existing standard conventional methods is a most important requirement that has not been met, but is essential if industry is to be encouraged to adopt these new approaches.

\section{Pre-amplification processing of samples}

The purpose of sample preparation is to homogenize the sample to be amplified, increase the concentration of the target to the practical operating qPCR sensitivity, and reduce or exclude amplification-inhibitory substances. Hence, preamplification treatment aims to convert food samples into amplifiable samples (Rådström et al., 2003). However, the efficiency and performance of qPCR can be negatively affected by the presence of inhibitory substances generally found in foods and nucleic acids extraction reagents (Wilson et al., 1997; Rossen et al., 1992). They can reduce or even block amplification reactions, leading to the underestimation or producing of false negative results. Thus, PCR-friendly sample preparation prior to the amplification reaction is crucial for the robustness and performance of $\mathrm{qPCR}$ methods, and is a priority for the implementation of qPCR methods as diagnostic tools in food laboratories.

Pre-amplification procedures should be adapted for each food type and analytical purpose as food samples vary in homogeneity, consistency and composition. A large range of pre-amplification procedures have been developed, but many of them are laborious, expensive, and time-consuming (Jaffe et al., 2001). Procedures can either be biochemical, immunological, physical or physiological (Rådström et al., 2003), or a combination of these (Table 1).

\section{Analytical controls}

Contamination is one of the principal concerns in food analysis laboratories. The main causes of production of false positive results are accidental contamination of the samples or the reagents with positive samples (crosscontamination) or with amplification products and plasmid clones (carry-over contamination). In addition, the efficiency of qPCR can be negatively influenced by several conditions including malfunction of equipment, incorrect reaction mixture, poor enzyme activity, or the presence of inhibitory substances in the original sample matrix. This can result in weak or negative signals and lead to underestimation of the amount of target in the sample. The potential presence of amplification inhibitors in the reaction is a serious problem that can compromise the applicability of $\mathrm{GPCR}$ in food analysis. Therefore, adequate control of the efficiency of the reaction is a fundamental aspect in such assays (Hoorfar and Cook, 2003; Rodríguez-Lázaro et al., 2007). A series of controls are recommended to correctly interpret the results of molecular techniques (Box 1).

Internal amplification controls (IACs)

Other fundamental aspects rely on the adequate control of the amplification reaction efficiency. In this sense, the application of internal amplification controls allows the assessment and interpretation of the diagnostic results of the molecular techniques. An internal amplification control 
Box 1. Analytical controls for molecular-based techniques. Adapted from Rodríguez-Lázaro et al. (2007)

Sample process control (SPC): A negative sample spiked with sufficient amount of target (e.g. pathogen, species, etc.), and processed throughout the entire protocol. A positive signal should be obtained indicating that the entire process (from nucleic acids extraction to amplification reaction) was correctly performed.

Negative sample process control (NSPC): A negative sample spiked with sufficient amount of nontarget or water, and processed throughout the entire protocol. A negative signal should be obtained indicating the lack of contamination along the entire process (from nucleic acids extraction to amplification reaction).

Environmental control: A tube containing the master mixture or water left open in the PCR set-up room to detect possible contaminating nucleic acids in the environment.

Positive PCR control: A template known to contain the target sequence. A positive amplification indicates that amplification was performed correctly.

Negative PCR control: Including all reagents used in the amplification except the template nucleic acids. Usually, water is added in stead of the template. A negative signal indicates the absence of contamination in the amplification assay.

Internal amplification control (IAC): Chimerical non-target nucleic acid added to the master mixture in order to be co-amplified by the same primer set as the target nucleic acid but with an amplicon size visually distinguishable or different internal sequence region from the target amplicon. The amplification of IAC both in presence and in the absence of target indicates that the amplification conditions are adequate.

or 'IAC' is a non-target nucleic acid sequence, which is coamplified simultaneously with the target sequence (Cone et al., 1992; Rodríguez-Lázaro et al., 2004, 2005). In a reaction without an IAC, a negative response (no signal) can mean that there was no target sequence present in the reaction. But, it could also mean that the reaction was inhibited. In a reaction with an IAC, a control signal will always be produced when there is no target sequence present. When no control signal is observed, this means that the reaction has failed, and the sample must be reanalysed. In a qPCRbased assay, an IAC should be based on flanking nucleic acid sequences with the same primer recognition sites as the target, with non-target internal sequences (RodríguezLázaro et al., 2004, 2005). The principal requirements of an optimal internal amplification control (IAC) for use in food diagnostic assays are reviewed in Hoorfar et al. (2004).

\section{Determination of viability}

The determination of bacterial viability is a key issue for the application of food risk management, and thus a rational approach to detect only viable bacterial cells by using molecular-based methods is necessary. However, PCRbased methods detect DNA which survives cell death. For this purpose the use of mRNA as template for amplification can be a promising solution (Klein and Juneja, 1997), though this requires removing any trace of bacterial DNA in the reaction in order to avoid false-positive results in viability assays (Cook, 2003). An alternative to RT-PCR, is the use of nucleic acid sequence-based amplification (NASBA) technique. NASBA is a potentially powerful technique for specific detection of viable cells. In contrast with RT-PCR, it does not required DNase treatment, since, as it runs at a single temperature in which dsDNA is not denatured and thus cannot became a substrate for NASBA.

A PCR-based approach has recently been devised to distinguish viable bacterial cells is the staining of cells with a blocking agent such as ethidium monoazide bromide (EMA) prior to DNA extraction and PCR to inhibit the amplification of DNA from dead cells (Nogva et al., 2003; Rudi et al., 2005a). This strategy combines the use of viability (livedead)-discriminating dye with the speed, specificity, and selectivity of amplification-based techniques such as qPCR. The principle is that these dyes do not penetrate the cell walls of viable cells, but will penetrate those of dead cells. They can intercalate in DNA and prevent amplification, and thus amplification signals will only be obtained from viable cells that the dye could not penetrate. EMA is a phenanthridinium nucleic acid-intercalating agent (Waring, 1965), and photolysis of EMA with visible light produces a nitrene that can form stable covalent links to DNA (Coffman et al., 1982; Hixon et al., 1975). The unbound EMA, remaining free in solution, is simultaneously photolysed and converted to hydroxylamine, and is no longer capable of covalent attachment to DNA (DeTraglia et al., 1978). Thus, the application of EMA prior to bacterial DNA extraction can lead to selective removal of DNA from dead cells. This approach has already been tested with different foodborne pathogens such as Escherichia coli 0157:H7 (Guy et al., 2006; Nocker et al., 2006; Nogva et al., 2003), Salmonella (Guy et al., 2006; Nocker et al., 2006; Nogva et al., 2003), Listeria monocytogenes (Guy et al., 2006; Nocker et al., 2006; Nogva et al., 2003, Rudi et al., 2005a;b), Campylobacter (Rudi et al., 2005a), and Vibrio vulnificus (Wang and Levin, 2005). However, it has been reported that EMA can also penetrate the membrane of viable bacterial cells and covalently cross-linked with the 
DNA during photolysis, resulting in loss of a percentage of the genomic DNA of viable cells and PCR inhibition (Nocker and Camper, 2006; Rueckert et al., 2005). This drawback can be overcome using a similar staining strategy with a more selective molecule such as propidium monoazide (PMA). PMA is a modification of propidium iodide that does not penetrate the membrane of viable cells, but is efficiently taken up by permeabilized cells (Nocker et al., 2006). Promising though this approach appears, it still contains a potential for ambiguity in that it is not completely assured that there are no circumstances in which dye is taken up by viable cells. In such circumstances, the potential for overlooking the presence of a pathogen in a food sample exists, and much further work is necessary before the dye approach can be confidently taken up in actual food analysis.

\section{Concluding remarks}

The continued guarantee of the safety and quality of foods, and the possession of means to meet the challenges posed by potential emerging threats, requires the development of novel, and refinement of existing, analytical methodology. In the last few decades substantial resources have been directed towards these efforts. However, the efforts have not for the most part been translated into tangible benefits for the consumer and stakeholder, since implementation of novel or improved methods has seldom been widespread, and in many cases has not occurred at all. There needs to be a focused drive towards taking proven methods from the scientist's laboratory and implementing them in actual use in the analyst's laboratory. This requires integration of the activities in method development and validation of the leading research groups. Very importantly, the involvement of manufacturing enterprises, food producers, retail companies, and food safety organizations is essential to ensure an informed, structured approach to quality and safety during the critical stages in food production processes. The pursuit of these objectives will require a major international initiative, but the reward would be manifested at all levels within the community.

\section{References}

Adak, G.K., Meakins, S.M., Yip, H., Lopman, B.A., and O'Brien, S.J. (2005). Disease risks from foods, England and Wales, 1996-2000. Emerg. Infect. Dis. 11, 365-372.

Coffman, G.L., Gaubatz, J.W., Yielding, K.L., and Yielding, L.W. (1982). Demonstration of specific high affinity binding sites in plasmid DNA by photoaffinity labelling with ethidium analogue. J. Biol. Chem. 257, 13205-13297.

Cone, R.W., Hobson, A.C., and Huang, M.L. (1992). Coamplified positive control detects inhibition of polymerase chain reactions. J. Clin. Microbiol. 30, 31853189.

Cook, N. (2003). The use of NASBA for the detection of microbial pathogens in food and environmental samples. J. Microbiol. Methods 53, 165-174.

Crutchfield, S., and Roberts, T. (2000). Food Safety efforts accelerate in 1990s. USDA, Economic Res. Service Food Rev. 23, 44-49.

D'Agostino M., and Rodriguez-Lazaro, D. (2009). Harmonization and validation of methods in food safety - 'FOOD-PCR', a case study. In Global Issues in Food Science and Technology. Barbosa-Cánovas, G., Mortimer,
A., Colonna, P., Lineback, D., Spiess, W., and Buckle, K., eds. (Maryland Height, USA: Academic press), pp. 199209.

DeTraglia, M.C., Brand, J.S., and Tometski, A.M. (1978). Characterization of azidobenzamidines as photoaffinity labelling for trypsin. J. Biol. Chem. 253, 1846.

Dieffenbach, C.W., Lowe, T.M.J., and Dveksler, G.S. (1995). General concepts for PCR primers design. In PCR primers: a laboratory manual. C.W. Dieffenbach and G.S. Dveksler, eds. (Cold Spring Harbour, NY, USA: Cold Spring Harbour Laboratory Press), pp. 133-142.

Eurobarometer No. 224. (2005). Available from http:// europa.eu.int/comm/public_opinion/archives/ebs/ ebs_224_report_en.pdf

Guy, R.A., Kapoor, A., Holicka, J., Shepherd, D., and Horgen, P.A. (2006). A rapid molecular-based assay for direct quantification of viable bacteria in slaughterhouses. J. Food Prot. 69, 1265-1272.

Heid, C.A., Stevens, J., Livak, K.J., and Williams, P.M. (1996). Real-time quantitative PCR. Genome Res. 6, 986-994.

Hixon, S.C., White, W.E., and Yielding, K.L. (1975). Selective covalent binding of an ethidium analog to mitochondrial DNA with production of petite mutants in yeast by photoaffinity labeling. J. Mol. Biol. 92, 319-329.

Hoorfar, J., and Cook, N. (2003). Critical aspects in standardization of PCR. In Methods in Molecular Biology: PCR Detection of Microbial Pathogens, K. Sachse and J. Frey, eds. (Totowa, USA: Humana Press), pp. 51-64.

Hoorfar, J., Malorny, B., Abdulmawjood, A., Cook, N., Wagner, M., and Fach, P. (2004). Practical considerations in design of internal amplification control for diagnostic PCR assays. J. Clin. Microbiol. 42, 1863-1868.

Jaffe, R.I., Lane, J.D., and Bates, C.W. (2001). Real-time identification of Pseudomonas aeruginosa direct from clinical samples using a rapid extraction method and polymerase chain reaction (PCR). J. Clin. Lab. Anal. 15, 131-137.

Klein, P.G., and Kuneja, V.J. (1997). Sensitive detection of viable Listeria monocytogenes by reverse transcriptionPCR. Appl. Env. Microbiol. 63, 4441-4448.

Malorny, B., Tassios, P.T., Rådström, P., Cook, N., Wagner, M., and Hoorfar, J. (2003). Standardization of diagnostic PCR for the detection of foodborne pathogens. Int. J. Food Microbiol. 83, 39-48.

Mead, P.S., Slutsker, L., Griffin, P.M., and Tauxe, R.V. (1999). Food-related illness and death in the United States. Emerg. Inf. Dis. 5, 607-625.

Nocker, A., and Camper, A.K. (2006). Selective removal of DNA from dead cells of mixed bacterial communities by use of ethidium monoazide. Appl. Environ. Microbiol. 72, 1997-2004.

Nocker, A., Cheung, C.Y., and Camper, A.K. (2006). Comparison of propidium monoazide with ethidium monoazide for differentiation of live vs. dead bacteria by selective removal of DNA from dead cells. J. Microbiol. Methods 67, 310-320.

Nogva, H.K., Dromtorp, S.M., Nissen, H., and Rudi, K. (2003). Ethidium monoazide for DNA-based differentiation of viable and dead bacteria by 5 '-nuclease PCR. Biotechniques 34, 804-813.

Rådström, P., Knutsson, R., Wolffs, P., Dahlenborg, M., and Löfström, C. (2003). Pre-PCR processing of sampling. In 
Methods in Molecular Biology: PCR detection of microbial pathogens. K. Sachse and J. Frey, eds. (Totowa, USA: Humana Press), pp. 31-50.

Rodríguez-Lázaro, D., D’Agostino, M., Pla, M., and Cook, N. (2004). A construction strategy for an internal amplification control (IAC) for real-time NASBA-based diagnostic assays. J. Clin. Microbiol. 42, 5832-5836.

Rodríguez-Lázaro, D., Pla, M., Scortti, M., Monzó, H.J., and Vazquez-Boland, J.A. (2005). A novel real-time PCR for Listeria monocytogenes that monitors analytical performance via an internal amplification control. Appl. Environ. Microbiol. 71, 9008-9012.

Rodríguez-Lázaro, D., Lombard, B., Smith, H., Rzezutka, A., D’Agostino, M., Helmuth, R., Schroeter, A., Malorny, B., Miko, A., Guerra, B., et al. (2007). Trends in Analytical Methodology in Food Safety and Quality: Monitoring Microorganisms and Genetically Modified Organisms. Trends Food Sci. Technol. 18, 306-319.

Rodríguez-Lázaro, D. (2013). Real-Time PCR in Food Science: Current Technology and Applications (Norfolk, UK: Caister Academic Press).

Rollins, D.M., and Colwell, R.R. (1986). Viable but nonculturable stage of Campylobacter jejuni and its role in survival in the natural aquatic environment. Appl. Environ. Microbiol. 52, 531-538.

Rossen, L., Nøskov, P., Holmstrøm, K., and Rasmussen, O.F. (1992). Inhibition of PCR by components of food samples, microbial diagnostic assays and DNA extraction solution. Int. J. Food Microbiol. 17, 37-45.

Rudi, K., Naterstad, K., Dromtorp, S.M., and Holo, H. (2005a). Detection of viable and dead Listeria monocytogenes on gouda-like cheeses by real-time PCR. Lett. Appl. Microbiol. 40, 301-306.
Rudi, K., Moen, B., Dromtorp, S.M., and Holck, A.L. (2005). Use of ethidium monoazide and PCR in combination for quantification of viable and dead cells in complex samples. Appl. Environ. Microbiol. 71, 1018-1024.

Rueckert, A., Ronimus, R.S., and Morgan, H.W. (2005). Rapid differentiation and enumeration of the total, viable vegetative cell and spore content of thermophilic bacilli in milk powders with reference to Anoxybacillus flavithermus. J. Appl. Microbiol. 99, 1246-1255.

Scallan, E., Hoekstra, R.M., Angulo, F.J., Tauxe, R.V., Widdowson, M.A., Roy, S.L., Jones, J.L., and Griffin, P.M. (2011). Foodborne illness acquired in the United States major pathogens. Emerg. Infect. Dis. 17, 7-15.

Scallan, E., Griffin, P.M., Angulo, F.J., Tauxe, R.V., and Hoekstra, R.M. (2011). Foodborne illness acquired in the United States - unspecified agents. Emerg. Infect. Dis. 17, 16-22.

Stewart, G.S. (1997). Challenging food microbiology from a molecular perspective. Microbiol. 143, 2099-2108.

Stirling, D. (2003). Quality control in PCR. Methods Mol. Biol. 226, 21-24.

Tholozan, J.L., Cappelier, J.M., Tissier, J.P., Delattre, G., and Federighi, M. (1999). Physiological characterization of viable-but-nonculturable Campylobacter jejuni cells. Appl. Environ. Microbiol. 65, 1110-1116.

Wang, S., and Levin, R.E. (2006). Discrimination of viable Vibrio vulnificus cells from dead cells in real-time PCR. J. Microbiol. Methods 64, 1-8.

Waring, M.J. (1965). Complex formation between ethidium bromide and nucleic acids. J. Mol. Biol. 13, 269-282.

Wilson, I.G. (1997). Inhibition and facilitation of nucleic acid amplification. Appl. Environ. Microbiol. 63, 3741-3751. 


\section{Further Reading}

Caister Academic Press is a leading academic publisher of advanced texts in microbiology, molecular biology and medical research. Full details of all our publications at caister.com

- MALDI-TOF Mass Spectrometry in Microbiology Edited by: M Kostrzewa, S Schubert (2016) www.caister.com/malditof

- Aspergillus and Penicillium in the Post-genomic Era Edited by: RP Vries, IB Gelber, MR Andersen (2016) www.caister.com/aspergillus2

- The Bacteriocins: Current Knowledge and Future Prospects Edited by: RL Dorit, SM Roy, MA Riley (2016)

www.caister.com/bacteriocins

- Omics in Plant Disease Resistance Edited by: V Bhadauria (2016) www.caister.com/opd

- Acidophiles: Life in Extremely Acidic Environments Edited by: R Quatrini, DB Johnson (2016) www.caister.com/acidophiles

- Climate Change and Microbial Ecology: Current Research and Future Trend

Edited by: J Marxsen (2016)

www.caister.com/climate

- Biofilms in Bioremediation: Current Research and Emerging Technologies

Edited by: G Lear (2016)

www.caister.com/biorem

- Microalgae: Current Research and Applications Edited by: MN Tsaloglou (2016) www.caister.com/microalgae

- Gas Plasma Sterilization in Microbiology: Theory, Applications, Pitfalls and New Perspectives Edited by: H Shintani, A Sakudo (2016) www.caister.com/gasplasma

- Virus Evolution: Current Research and Future Directions Edited by: SC Weaver, M Denison, M Roossinck, et al. (2016) www.caister.com/virusevol

- Arboviruses: Molecular Biology, Evolution and Control Edited by: N Vasilakis, DJ Gubler (2016) www.caister.com/arbo

- Shigella: Molecular and Cellular Biology Edited by: WD Picking, WL Picking (2016) www.caister.com/shigella

-Aquatic Biofilms: Ecology, Water Quality and Wastewater Treatment

Edited by: AM Romaní, H Guasch, MD Balaguer (2016)

www.caister.com/aquaticbiofilms

- Alphaviruses: Current Biology

Edited by: S Mahalingam, L Herrero, B Herring (2016)

www.caister.com/alpha

- Thermophilic Microorganisms

Edited by: F Li (2015)

www.caister.com/thermophile
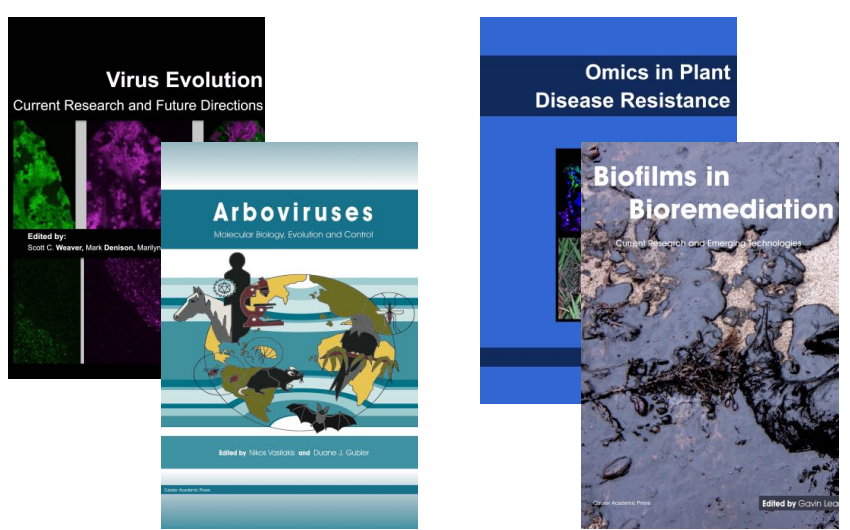
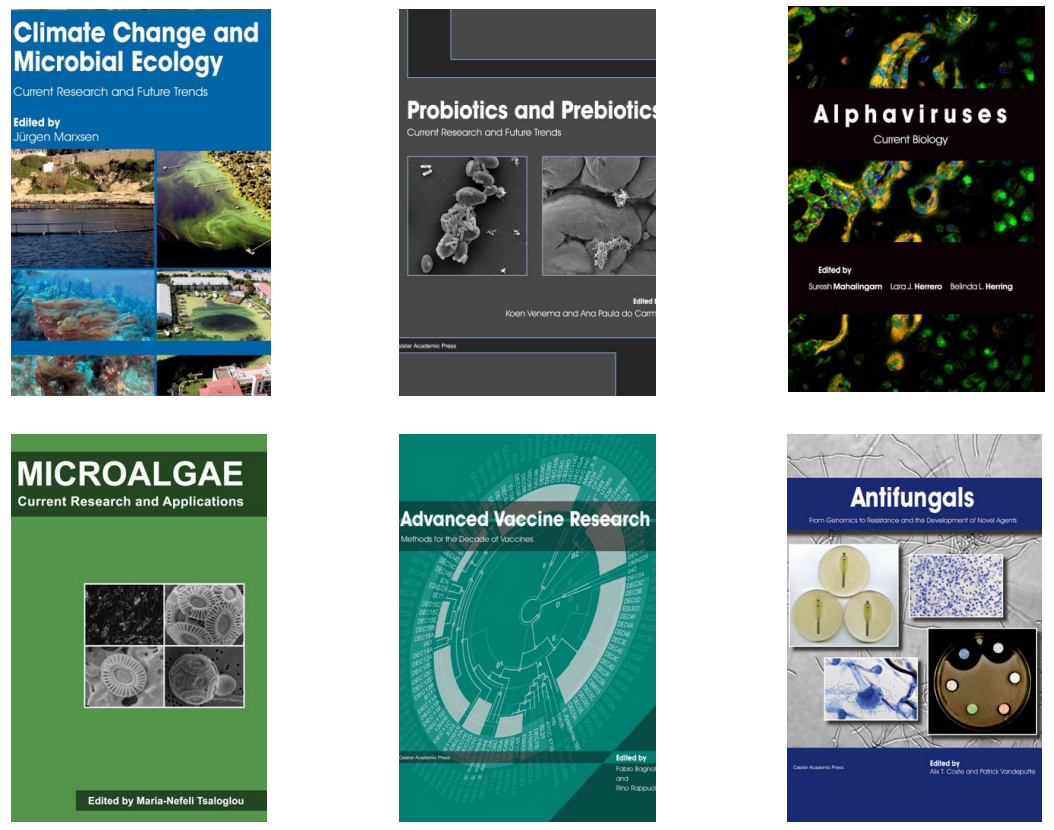

- Flow Cytometry in Microbiology: Technology and Applications Edited by: MG Wilkinson (2015) www.caister.com/flow

- Probiotics and Prebiotics: Current Research and Future Trends Edited by: K Venema, AP Carmo (2015) www.caister.com/probiotics

- Epigenetics: Current Research and Emerging Trends Edited by: BP Chadwick (2015) www.caister.com/epigenetics2015

- Corynebacterium glutamicum: From Systems Biology to Biotechnological Applications

Edited by: A Burkovski (2015)

www.caister.com/cory2

- Advanced Vaccine Research Methods for the Decade of Vaccines

Edited by: F Bagnoli, R Rappuoli (2015)

www.caister.com/vaccines

- Antifungals: From Genomics to Resistance and the Development of Novel Agents

Edited by: AT Coste, P Vandeputte (2015)

www.caister.com/antifungals

- Bacteria-Plant Interactions: Advanced Research and Future Trends Edited by: J Murillo, BA Vinatzer, RW Jackson, et al. (2015) www.caister.com/bacteria-plant

\section{- Aeromonas}

Edited by: J Graf (2015)

www.caister.com/aeromonas

- Antibiotics: Current Innovations and Future Trends

Edited by: S Sánchez, AL Demain (2015)

www.caister.com/antibiotics

- Leishmania: Current Biology and Contro Edited by: S Adak, R Datta (2015) www.caister.com/leish2

- Acanthamoeba: Biology and Pathogenesis (2nd edition) Author: NA Khan (2015)

www.caister.com/acanthamoeba2

- Microarrays: Current Technology, Innovations and Applications Edited by: Z He (2014)

www.caister.com/microarrays2

- Metagenomics of the Microbial Nitrogen Cycle: Theory, Methods and Applications

Edited by: D Marco (2014)

www.caister.com/n2 